\title{
Municipal Consumer Debt in South African Municipalities: Contexts, Causes, and Realities
}

\author{
Prince Chukwuneme Enwereji ${ }^{1} \&$ Dominique Uwizeyimana ${ }^{1}$ \\ ${ }^{1}$ School of Public Management, Governance \& Public Policy, College of Business and Economics, University of \\ Johannesburg, South Africa \\ Correspondence: Prince Chukwuneme Enwereji, School of Public Management, Governance \& Public Policy, \\ College of Business and Economics, University of Johannesburg, South Africa.
}

Received: March 9, 2020

doi:10.5430/rwe.v11n3p333
Accepted: April 29, 2020

Online Published: June 30, 2020

URL: https://doi.org/10.5430/rwe.v11n3p333

\begin{abstract}
The payment for municipal services by the residents in South Africa has been a much-deliberated issue as consumer debts in many municipalities continue to intensify due to payment default or non-payment. The main aim of this study was to investigate the development of non-payment culture for municipal services, the main causes of non-payment for municipal services, and the measures to improve the payment culture for municipal services. This study adopted a mixed-methods research approach incorporating both quantitative and qualitative research approaches. A convergent parallel mixed methods design was adopted which enhanced the richness of data by triangulating the findings from quantitative and qualitative datasets. Data was collected from the residents using questionnaires and online interviews with executive municipal employees. Findings obtained from the study indicate that the non-payment culture for municipal services has its origin from the anti-apartheid struggle. Furthermore, it was disclosed that the reasons for non-payment for municipal services are compounded as poverty, unemployment, the culture of entitlement, dissatisfaction with service provision, corruption of municipal workers, rise in the cost of municipal services, communication gap issues, and problems associated with the municipal decision-making process. The study recommends that the municipalities should provide adequate services to the residents and adequately engage in a wide outreach to residents through various electronic media or IDP programmes to educate them on the advantages of paying for the services consumed.
\end{abstract}

Keywords: municipal services, payment for services, residents, municipal employees, municipalities, South Africa

\section{Introduction}

Local municipalities will perform exceedingly in their service provision bid if they can mobilise all payments from residents who consume municipal services. In South Africa, municipalities are the third arm of government and operate close to the local communities or wards. Local municipalities are responsible to provide services such as water, electricity, sewerage reticulation, sanitation, road maintenance, etc. These services are partly funded through the intergovernmental fiscal transfers from the national government and the imposition of taxes, fees, licences, rates or surcharges as constitutionally mandated. Mobilising payment from residents for these services provided by municipalities has been a contentious issue in South Africa (Enwereji \& Potgieter, 2018). The inability to mobilise payments from owing and defaulting residents has escalated the consumer debt of municipalities and has contributed to dwindling the quality of services provided. Enwereji and Kadama (2018) affirm that the efficient management of debts in any business establishment is of paramount standing for businesses, however, local municipalities are no exception, despite not being a business entity.

Consumer debt refers to the inability for municipal service consumers to pay for the municipal services consumed (Financial \& Fiscal Commission, 2018). The magnitude of consumer debt of South African municipalities has been an issue of concern. The National Treasury (NT) (2017) affirms that the total municipal debt in 2016 amounts to 117 billion rands. In the second quarter of 2017, it rose to R138 billion rand and settled at R138.2 towards the end of 2017. In 2018, NT (2018) affirm that municipal debt in the 257 municipalities rose to R184.7 billion rand of which consumer debt holds two-thirds (68\%) of this amount (other debtors $24 \%$, VAT receivable $8 \%$, \& short term loans 0.02\%). Concerning consumer debt, different scholars, such as Enwereji and Uwizeyimana (2019), Worku (2016), Khale (2015), Kanyane (2014), Manyaka (2014) and Powell et al. (2010) have investigated the reasons for payment 
default and non-payment for municipal services. These studies assert that the reasons for the escalating consumer debt may include the rise in the cost of municipal services, unemployment, poor service provision and political discouragement. Several recommendations have also been made to stem the escalating consumer debt such as to educate residents (Oladipupo \& Obazee, 2016), communicate with residents (Leonard, 2018), provide required services (Fjielstad et al., 2012; Enwereji \& Potgieter, 2018), circulate annual budget (Al-Maghrebi et al., 2016), engage in innovative measures (Horth \& Bunchner, 2014); deter defaulting residents (Mascagni, Nell \& Monkam, 2017) and apply the contents of law (Enwereji \& Kadama, 2018).

It is, however, a considered critical factor for municipal workers to understand the relationship between the provision of municipal service and payment for such service. Most residents ascribe their non-payment attitude towards the inability of municipalities to provide equitable service while municipalities attribute their lapses in service provision to the inability of residents to pay for the services consumed (Enwereji, 2018). The existing rifts between the residents and municipalities have resulted in service provision protests which have claimed so many lives, burning and looting of public properties. In 2012, (173) service provision protests were recorded, in 2013 (155), 2014 (191), 2015 (164), 2016 (137), 2017 (173) and (237) in 2018 (Joel, 2020). However, the study of Marivete (2014) and Khale (2015) highlight that residents embark on service provision protests due to poor service delivery, lack of performance monitoring, lack of appraisal systems, lack of technical and managerial expertise, misuse and mismanagement of limited municipal resources, deterioration of property and infrastructure, and municipal workers' financial misappropriation.

Considering the intensity of non-payment for municipal services, the National Treasury (2018) concurs that it is strictly an entitlement mentality of the residents. The entitlement issue is illustrated in a municipal area such as Soweto where some residents have refused to pay for electricity. Residents in Soweto owe a huge sum of R18bn to Eskom which threatens its financial standing and poses financial burdens to South Africa at large (Joel, 2020). Due to the non-payment culture, service consumers have owed tangible sum to municipalities, and in turn, push municipalities to be indebted to water boards, Eskom, road construction companies and other service provision agents. This stands as one of the biggest credit risks to the South African nation. Joel (2020) affirms that in June 2019, consumer debt rose to R165.5 billion, where household debts amount R118 billion, business R25 billion, and government R10.3 billion. Notwithstanding, several municipalities cannot collect debts from the residents due to lack of financial capacity to provide equitable services or enforcement capacity to collect debts as enshrined by the Constitution of South Africa (1996). This paper investigates the reasons for default and non-payment for municipal services, the origin, causes and the solutions to enhance the payment culture of residents. The subsequent section traces the historical development of non-payment culture.

\section{Historical Development of Non-payment for Municipal Services in South Africa}

The issue of non-payment for municipal services has its legacy in the anti-apartheid struggle wherein a sense of entitlement to services has been bandied as a dividend of democracy (Johnston, 2014). The non-payment for municipal services originated in the black-dominated areas in the 1980s during the Apartheid era (Moses, 2002). South Africa is categorised today as a heterogeneous society consisting of varied cultures, races and economic circumstances. During the Apartheid era, towns and city councils were divided into two groups. The first group catered for black communities while the other catered for white municipal areas (Binza, 2000). City councils that were positioned to cater for blacks were unable to provide adequate services and there was also an imbalance in resource allocation towards the development of black-dominated areas, compounded by the inability of blacks to pay for municipal services such as water, electricity, sanitation, stormwater drainage and sewerage systems provided by municipalities (Sithole \& Mathonsi, 2015). The consistent default on the payment of municipal services resulted in poor service delivery that culminated in power failures, insufficient water provision and poor sanitation (Moses, 2002). Moses (2002) further shows that the black-dominated areas witnessed widespread diseases such as typhoid, hepatitis B and cholera, as well as, massive environmental pollution associated with the problem of poor refuse collection and disposal. While the Apartheid administration waited in vain to receive service payments from the black-dominated areas, the white municipal leaders ensured that they did not provide adequate services to the black communities. More so, it should be noted that service payments received from black communities were used by the municipalities to provide more improved services to the already affluent white areas (DBSA Report, 1998).

The leaders of Apartheid delegated authority to black councils and councillors, who were regarded by blacks as apartheid's stooges for the further oppression of the masses (Christianson, 1994). These councils and councillors of the black-dominated areas were also seen by their communities to be hindering the pace of development due to corruption-related reasons (Christianson, 1994). Most of the historically disadvantaged blacks in South African 
municipalities fought and challenged the discriminatory method of the Apartheid system of government in numerous ways, which today still includes demonstrations, riots, protests, strikes and collective crowd action in public places, especially at municipal buildings and offices (Christianson, 1994). Nevertheless, mass action by the neglected black majority tended to have a significant effect. The rent and rates boycotts were often worsened by anger over the ejection of residents in these areas.

The process of amalgamating black and white councils during the 1980s and 1990s was riddled by contestations over legitimacy. This circumstance gave birth to continued conflict as people believed that councillors and councils do not represent the interests of the residents (Christianson, 1994). Some political organisations, such as the African National Congress (ANC), used this medium to weaken the hold of Apartheid by making black-dominated areas ungovernable. More so, the ANC goaded stay-away action and encouraged black communities to withhold payment for municipal services such as rent, rates and tax payments in retaliation against the poor quality and/or lack of service provision in their areas (Moses, 2004). The ANC viewed and voiced that apartheid leadership was undemocratic and racially biased, which resulted in the defiant actions of blacks getting legitimacy and justification.

With due respect to the activities of the black-dominated municipalities that embraced the inability to provide adequate services, non-payment for municipal services escalated. However, it appears that another facet has been added to the non-payment fiasco as it is currently used to damage the reputation of the ruling ANC government since the promises made in 1994 are yet to be fulfilled. In a conventional view, the non-payment for municipal services is today not as politically motivated as it used to be but many consumer debts today are incurred due to unemployment, poverty or so many other reasons. Kroukamp (1995) posits that the inability to pay for municipal services was originally exhibited to fight against the inequitable service provision between white and black dominated municipalities. However, protests in the form of payment boycotts became a culture which has been adopted by a large section of the consumers in the South African municipal services context. The subsequent discussion elucidates the reasons for payment default of municipal services.

\section{Reasons for Payment Default and Non-payment for Municipal Services}

Numerous reasons have been identified by several scholars as to the reasons for non-payment and payment default for municipal services. In the view of Powell et al. (2010), there is evidence of social unrest and uprisings today in many local municipalities in South Africa and this is due to the inability of municipal role-players to enhance effective governance and to provide adequate municipal services to their residents. Powell et al. (2010) further mention that many municipalities in South Africa have witnessed the destruction of municipality buildings and the burning of schools and government properties due to conflict arising from poor service provision. Some residents of Moqhaka, Ngwethe, Tswaing, Madibeng and the Nokengtsa Taemane municipalities defaulted to pay for municipal services due to poverty and tribal issues. Consistent with this, Kanyane (2014) and Manyaka (2014) further indicate that the reasons for the non-payment problem have, however, been overcome by other reasons recently, which include poverty, unemployment, political issues, entitlement issues and opportunism. The compendium of these factors contributing to non-payment and payment default is highlighted as inadequate service provision by the municipalities, poverty, unemployment, mismanagement of public funds, the culture of entitlement, decision-making issues, and maladministration and poor governance of municipal workers.

The subsequent sections deal with each on the causes of non-payment and payment default for municipal services in numerous municipalities of South Africa.

\subsection{Inadequate Service Provision}

Service delivery involves providing services such as electricity, sewerage, sanitation, pipe-borne water and other municipal services to residents at an affordable rate (Kanyane, 2014). Adequate service provision demands that municipal role-players should ensure that there ought to be a steady supply of essential services to residents and constant maintenance of equipment for service delivery (Powell et al., 2010). Kenyane (2014) maintains that inadequate service provision has led to mass protests and civil unrest throughout many municipalities in South Africa. Consumers boycott payment due to frustration with the trend of service provision by municipalities. The payment boycotts by consumers are intended to influence service providers to improve service provision. According to Powell et al. (2010), payment boycotts have been employed by residents of South Africa in different circumstances for residents to benefit more from the dividends of democracy.

\subsection{Poverty as a Reason for Non-payment of Municipal Services}

Poverty accounts for payment default for municipal services. According to a survey conducted by Statistics South Africa in 2015, it is conspicuously clear that poverty in South Africa is on the rise and this fact undoubtedly 
contributes towards the failure to pay for municipal services. The All Media Products Survey (AMPS) of the South African Advertising Research Foundation (2015) specifies that the fraction of people who live in poverty in South Africa increases every year. This creates a stark picture of the financial challenges of the South African population at large. Following is a presentation of poverty headcount by age in South Africa in 2006, 2009, 2011 and 2015.

Table 1 depicts that despite the measures implemented to reduce the poverty rate from 2006 to 2011 , poverty levels in South Africa increased in 2015. More than half of the South African population is deemed poor in 2015 as the poverty headcount increased to $55.5 \%$, up from $53.2 \%$ in 2011 . These facts are further calculated using the upper-bound poverty line (UBPL) of R992 per person per month (pppm) in 2015 prices. This depicts that more than 30.4 million South Africans lived in poverty during 2015. This is substantially better when compared to the 2006 results where two-thirds of South Africans (66.6\% or 31.6 million people) lived below the poverty level.

Table 1. Poverty headcount by age in South Africa

$(2006,2009,2011 \& 2015)$

\begin{tabular}{ccccc}
\hline \multirow{2}{*}{ AGE } & \multicolumn{4}{c}{ YEAR AND PERCENTAGES OF POVERTY } \\
\cline { 2 - 5 } & 2006 & 2009 & 2011 & 2015 \\
\hline $0-17$ & $77.5 \%$ & $73.4 \%$ & $63.7 \%$ & $66.8 \%$ \\
\hline $18-24$ & $70.3 \%$ & $66.3 \%$ & $58.6 \%$ & $60.1 \%$ \\
\hline $25-34$ & $57.3 \%$ & $55.1 \%$ & $47.1 \%$ & $61.0 \%$ \\
\hline $35-44$ & $55.2 \%$ & $50.0 \%$ & $42.1 \%$ & $45.0 \%$ \\
\hline $45-54$ & $53.6 \%$ & $49.0 \%$ & $40.4 \%$ & $42.2 \%$ \\
\hline $55-65$ & $55.0 \%$ & $50.3 \%$ & $42.3 \%$ & $43.3 \%$ \\
\hline $65+$ & $64.7 \%$ & $53.4 \%$ & $43.2 \%$ & $44.0 \%$
\end{tabular}

Source: Statistics South Africa (2015)

\subsection{Unemployment as a Cause of Non-payment}

Unemployment refers to a situation where able men and women who are searching for jobs do not have one. Kenyane (2014) and Powell et al. (2010) affirm that unemployment is one of the major problems causing non-payment for municipal services in some of the municipalities, especially the North West province. Table 2 presents the South African unemployment rate in 2015, 2016 and 2017.

Table 2 depicts that South Africa's unemployment rate in January 2015 was at $24.3 \%$ and this rose to $27.7 \%$ in July 2017. The average unemployment level in South Africa from 2015 to 2017 is at $25.50 \%$. Unemployment poses a problem to consumers as they further live below the poverty line, thus finding it difficult to pay for their municipal services consumed (Powell et al., 2010). In some circumstances, many consumers are pensioners and provincial grant-holders who do not have an adequate income to live, not to mention paying for municipal services. This situation should attract the implementation of indigent policies by municipalities or by giving subsidies to disadvantaged households to pay a flat rate for their services consumed. The flat rate paid by consumers may be negotiated with municipalities. 
Table 2. South Africa's unemployment rate (2015-2017)

\begin{tabular}{ccccccc}
\hline \multicolumn{7}{c}{$\begin{array}{c}\text { UNEMPLOYMENT RATE } \\
\text { IN \% }\end{array}$} \\
\hline MONTH & 2015 & 2016 & 2017 & 2018 & 2019 & 2020 \\
\hline January & 24.3 & 24.5 & 26.6 & 27.0 & 27.1 & 29.1 \\
\hline July & 25.0 & 26.6 & 27.7 & 27.5 & 29.1 & 35.3 \\
\hline December & 25.5 & 27.1 & 27.7 & 27.1 & 29.1 & - \\
\hline AVERAGE & 24.9 & 26.1 & 27.3 & 27.3 & 28.4 & 29.1 \\
\hline
\end{tabular}

Source: Statistics South Africa (2019).

\subsection{Mismanagement of Public Funds by Municipal Role-Players}

Many consumers perceive municipal financial administration as being poorly managed and sometimes boycott the payment for municipal services due to the perceived mismanagement. This suspicion is nursed by the decay and breakdown of infrastructure and shortages, as evidenced by poor service provision incidents reported in the media. Studies such as Timm and Jadwat (1998) indicate that inadequate funding and failure to fulfil promises made by incoming councillors has led residents to suspect that role-players do not only mismanage but also loot public funds. Unfulfilled promises and the inability to enforce payment compliance on defaulters cumulatively cause service consumers to get the impression that public funds are indeed mismanaged.

\subsection{Culture of Entitlement}

Bellamy (2008) concurs with Toulmin (2008) and with Binswanger-Mkhize et al. (2009), Sikor and Lund (2010) and Lund (2011) that an entitlement mentality has led to non-payment for municipal services. Sikor and Lund (2010) mention that consumers are convinced that the provision of municipal services is the responsibility of municipalities. Therefore, consumers are entitled to service provision as a dividend of democracy. More so, Lund (2011) affirms that some consumers in South Africa boycott payment for municipal services due to land rights and citizenship, which gave them the conviction that land and all municipal services are for free and should not be paid for.

\subsection{Decision-Making Issues}

Section 4 of the Municipal Property Rates Act (No 6 of 2004) specifies that municipal role-players should encourage community participation in decision-making processes on matters concerning billing and rates of services. This section of the Act also indicates that municipal role-players should provide the necessary information concerning proposed property rates to residents and invite their inputs and comments at least 30 days before discussing and adopting such decision and policies. In recent times, South African municipal consumers feel dissatisfied when they are not involved in making decisions concerning service provision and matters related to the payment for service provision. Consistent with this, Kenyane (2014) affirms that consumers in South Africa should be included in decision-making processes because it has in the past, and will do so in future, lead to payment boycotts by consumers because they feel the decisions made by role-players are against them and their wishes.

\subsection{Maladministration and Poor Governance of Municipal Workers}

The reasons for the non-payment of municipal services in South Africa, according to Kelly (2013), are poor metering, inaccurate billing systems, the inability to promote electronic payment enhancements, and also improper enforcement on payment default. Municipalities, according to Manyaka (2014), should improve their administration and must hire competent staff to achieve adequate service delivery.

The next delineation presents the research methodology of this study.

\section{Research Methodology}

The main aim of this study was to peruse the development of non-payment culture for municipal services, the main causes of non-payment for municipal services, and soluble measures to improve the payment culture for municipal services. This study is drawn from a pragmatist perspective which allows for pluralistic approaches in solving research problems (Creswell, 2014). In this regard, a mixed methods research approach was considered in the study, incorporating both quantitative and qualitative attributes. A convergent parallel mixed-methods design was applied. Ivankova (2015) affirms that a convergent mixed methods research design involves the process by which both 
quantitative and qualitative data are collected concurrently, analysed separately and discussed in a holistic technique. It helps to discover existing contradictions and similarities in research findings (Creswell, 2014; DeCuir-Gunby \& Schutz, 2017).

In the quantitative study, 384 residents were drawn as a sample representation across four district municipalities of the North West province. The residents drawn for this study are those that live in the municipal area and do pay municipal bills as well. Residents that do not live in the municipal areas or do not pay for municipal bills are excluded in this study. Questionnaires were used to collect data from the residents. Out of the 500 distributed questionnaires, 359 usable questionnaires were received making a response rate of $93 \%$. With a response rate of $93 \%$, the study is said to have collected adequate data to arrive at valid conclusions. Data collected in this phase was analysed using the Statistical Package for Social Sciences (SPSS, version 24). Descriptive and inferential statistics were obtained in the quantitative dataset. Findings were presented afterwards.

In the qualitative study, 92 municipal employees were selected purposively to participate in the study. The employees purposively selected are those that are involved in the active management of the payment for municipal services. Employees that are not involved in the management of services are excluded. An online interview was adopted to collect data from municipal employees due to time constraints. Atlas-ti software (version 8.4) was used to analyse data collected from the structured interviews. Processes such as transcription of data, initial coding of data, coding of data, representation of data, and interpretation and summarizing of findings were observed during the qualitative data analyses.

In the presentation phase, data from quantitative phase were presented followed by the qualitative dataset. Findings from both quantitative and qualitative datasets and the literature review findings further triangulated. Similarities and contradictions were expounded upon in an endeavour to find solutions to the research problem. In the entire research process, ethical concepts applicable to the study were observed. Practices such as voluntary participation and exit, anonymity and confidentiality of responses, and protection of participants against harm were observed. The researcher avoided over-pressing the participants during the interview session, also all the sources used in the study were duly referenced or acknowledged.

\section{Presentation of Research Results}

Concerning the design of this study (convergent parallel mixed methods), the quantitative results are presented followed by the qualitative results. The discussions were made thereafter to suit the purpose of the study.

\subsection{Presentation of Quantitative Results}

In the descriptive analysis, the following are the summary of biographical details of the respondents:

- More residents from Mahikeng municipality participated in this study

- Almost $30 \%$ of the respondents do not pay for their municipal services

- About $40 \%$ of the respondents default at intervals in the payment for their services.

- More residents pay R501-R1000 as municipal service fees

- Respondents agreed that the municipal role-players have adequate experience on matters related to the payment of municipal services. This indicates that they have adequate experience to enhance a responsible payment culture for municipal services

- More residents in the study receive at least R21 000 as monthly income which signifies that they can be able to pay for municipal services

- More residents have lived for at least 21 years in their respective municipalities indicating that they are knowledgeable to attend to questions regarding the non-payment for municipal services

- The respondents indicated that the highest role-player in the municipalities are the politicians followed by the municipal employees

- Majority of the respondents have access to email accounts, private postal mailboxes, mobile phones, mobile phones with the Internet, access to social media accounts and access to nearby ATMs. Few respondents indicated that they do not have access to desktops with the Internet.

Table 3 presents the descriptive dataset on reasons for payment default. 
Table 3. Reasons for payment default for municipal services

\begin{tabular}{llllll}
\hline & Responses & SA (\%) & A (\%) & D (\%) & SD (\%) \\
\hline 1 & Unemployment & 12 & 8 & 23 & 57 \\
\hline 2 & Inability to pay my bills & 3 & 18 & 42 & 37 \\
\hline 3 & Many financial obligations & 14 & 55 & 16 & 15 \\
\hline 4 & Discrepancies in my bills & 40 & 41 & 17 & 2 \\
\hline 5 & Lack of payment enforcement & 12 & 41 & 27 & 20 \\
\hline 6 & Poor service provision & 38 & 50 & 8 & 4 \\
\hline 7 & Decision making issues & 30 & 45 & 7 & 8 \\
\hline 8 & Mismanagement of public funds & 51 & 32 & 11 & 6 \\
\hline 9 & Poverty & 7 & 30 & 31 & 32 \\
\hline 10 & Culture of entitlement & 40 & 34 & 11 & 15 \\
\hline 11 & Corruption of municipal officers & 55 & 36 & 4 & 5 \\
\hline 12 & Political discouragement & 28 & 32 & 24 & 16 \\
\hline 13 & Nepotism in billing system & 4 & 43 & 51 & 2 \\
\hline 14 & Lack of proper appeal system & 45 & 20 & 25 & 10 \\
\hline
\end{tabular}

Note: $\mathrm{SA}=$ strongly agree, $\mathrm{A}=$ agree, $\mathrm{D}=$ disagree, $\mathrm{SD}=$ strongly disagree

According to Table 3, more respondents indicated their agreement that corruption of municipal officers (91\%), poor service provision (88\%), decision-making issues (85\%), mismanagement of public funds (83\%), and discrepancies in billing system are the main causes of non-payment for municipal bills. Others are the culture of entitlement (74\%), many financial obligations (69\%), lack of appeal system (65\%), political discouragement (60\%) and lack of payment enforcement mechanisms (53\%). Furthermore, more respondents disagreed that unemployment $(80 \%)$, inability to pay bills (79\%), poverty (63\%), and nepotism in the billing system (53\%) are the causes of payment default for municipal services.

Table 4 presents the correlation analysis between payment default and matters related to payment for municipal services.

Table 4. Correlation between payment default and matters related to payment

\begin{tabular}{lll}
\hline Views assessed & The correlation coefficient $(\mathbf{r})$ & p-value \\
\hline Unemployment & 0.116 & 0.000 \\
\hline Inability to pay my bills & 0.124 & 0.003 \\
\hline Many financial obligations & 0.132 & 0.000 \\
\hline Discrepancies in my bills & 0.113 & 0.003 \\
\hline Lack of payment enforcement & 0.211 & 0.005 \\
\hline Poor service provision & -0.125 & 0.000 \\
\hline Decision making issues & -0.206 & 0.008 \\
\hline Mismanagement of public funds & -0.100 & 0.042 \\
\hline Poverty & -0.214 & 0.000 \\
\hline Culture of entitlement & 0.122 & 0.043 \\
\hline Corruption of municipal officers & 0.135 & 0.013 \\
\hline Political discouragement & 0.143 & 0.012 \\
\hline Nepotism in billing system & 0.221 & 0.011 \\
\hline Lack of proper appeal system & 0.137 & 0.004 \\
\hline
\end{tabular}


It is observable in Table 4 that all p-values obtained are less than the 0.05 level of significance which denotes that there is a significant correlation between payment default and matters related to payment for municipal services. Invariably, the positive correlations obtained imply that residents who have been paying rates for a long time tend to disagree with the listed items and vice versa.

\subsection{Presentation of Qualitative Results}

After the interviews were done, Atlas-ti software (version 8.4) was used to analyse data after observing all the processes as indicated in the research methodology. Themes and categories were developed and represented in a network diagram. The theme, in this case, refers to the research focus while category refers to the responses from the participants.

Figure 1 presents the network diagram of the qualitative dataset.

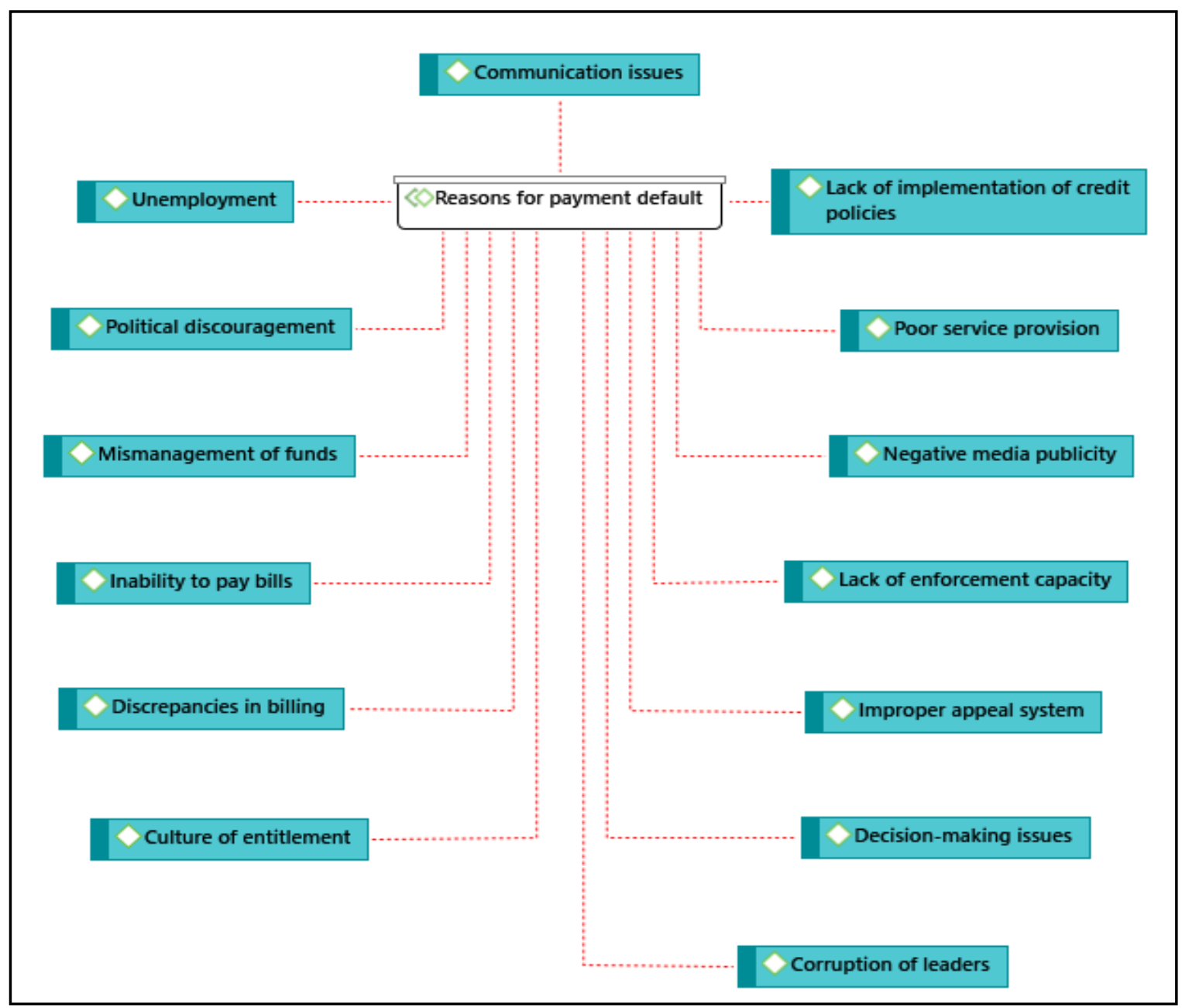

Figure 1. Participants' views on the causes of payment default

According to Figure 1, participants affirmed that the causes of payment default for municipal services include communication issues, lack of implementation of credit policies, poor service provision, negative media publicity, lack of enforcement capacity, improper appeal system, decision-making issues, corruption of leaders, the culture of entitlement, discrepancies in the billing system, inability to pay bills, mismanagement of funds, political discouragement and unemployment. 


\section{Discussion of Research Results}

The results from both quantitative and qualitative datasets indicate various reasons for non-payment and payment default of municipal services. There is an agreement by both residents and municipal workers that lack of payment enforcement, lack of implementation of credit policies, poor service provision and decision making issues do contribute to payment default by residents. Lack of enforcement capacity and the inability to apply municipal credit policies is among the major causes of payment default, Powell et al. (2010) and Enwereji (2018) opines that most municipalities have failed to apply the prescripts of Constitution of South Africa (No. 108 of 1996), Municipal Property rates Act (6 of 2004), Municipal Systems Act (32 of 2000), Water Service Act (108 of 1997), Municipal Structures Act (117 of 1998), Public Financial Management Act (1 of 1999), Municipal Finance Management Act (56 of 2003), National Credit Act (34 of 2005), Municipal Fiscal Powers and Functions Act (12 of 2007), Consumer Protection Act (Act 68 of 2008), and other Municipal service provision by-laws to enforce payment from residents. Poor service provision was also highlighted by participants of this study as a reason for payment default. In the study of Kanyane (2014), poor service provision has led to payment boycotts by several municipalities which erupted to service delivery protests resulting in damage to public properties. Concerning decision-making issues, Municipal Property Rates Act (No 6 of 2004) affirms that residents should be incorporated in decision-making concerning service provision matters. The inability to consider residents' inclusion in decision-making has led to payment boycotts (Kanyane, 2014).

The quantitative and qualitative datasets agree that mismanagement of public funds and corruption of municipal officers further constitute to non-payment for municipal services. Manyaka (2014) and Enwereji and Kadama (2018) pinpoint that appropriate financial management is needed in municipalities to ensure effective service provision and maintenance of infrastructure. In the absence of fulfilling promises by role-players such as good infrastructure and equitable service provision, residents do gather the impression that the municipal workers are corrupt, hence embezzle or mismanage their public funds (Timm \& Jadwat, 1998). Regarding political discouragement and culture of entitlement, both datasets concurred that it constitutes to non-payment for municipal services by residents. During the interviews, municipal workers highlighted that there is a lack of collaboration between the councillors and the municipal workers which result in councillors' reluctance to encourage the residents to pay for services consumed. Furthermore, the culture of entitlement as highlighted by the participants of this study emerged as one of the causes of a payment default. Entitlement issue has been identified by Lund (2011) as the major reason for payment default for municipal services. The entitlement issue has been evidenced in Soweto where most residents have refused to pay for electricity and owe the sum of R18bn to Eskom. Lund (2011) and Sikor and Lund (2010) pinpoint that service consumers boycott payment due to land rights and the feeling that service delivery should be free to all citizens. Other similarities that emerged in the study include discrepancies in the billing system and lack of appeal system. In the interviews, participants testified that discrepancies in billing discourage residents to pay their bills, also proper appeal system to follow-up the discrepancy in billing. Consequent to this, the local municipalities are required to compile appropriate bills, send reminders or demand for payment from the residents as prescribed by Section 6 (2) (c), (e) and (f) and 95 (2), (c), (e), and (f) of the Local Municipal Systems Act (32 of 2000). Concerning the lack of proper appeal system that was highlighted in the datasets, Municipal Property Rates Act (6 of 2004) Section 50 specifies that residents should forward complaints to the municipalities on objections and further valuation of bills.

The main findings revealed by this study indicate that corruption of municipal officers, poor service provision, decision-making issues, and mismanagement of public funds are the main causes of a payment default. It was also discovered that unemployment, poverty, and inability to pay bills are no cogent reasons for payment default. These reasons were opposed in the interview session where municipal workers vividly explained the contents of indigent policies. While more respondents in the quantitative study disagree that unemployment, inability to pay bills and poverty are the reasons for non-payment, the participants in the qualitative study further concurred that most residents hide under the guise of unemployment to default in the payment for the services consumed. However, the municipal workers emphasized that Section 15 of MPRA (6 of 2004) and other applicable legislation provides that municipalities may consider rebates to indigent residents on the amount payable. However, most residents are employed but claim to be indigent while the residents that are considered indigent fail to report to the municipality for proper documentation. Other findings in the qualitative datasets include communication issues and negative publication or negative feelings about the municipal workers. Sauer (2014), Fielding and Plooy-Cilliers (2014), de Mooij (2014) and USAID (2013) explain the need to constantly communicate with the residents to expound on when they are expected to pay their bills. Furthermore, the participants indicated that negative publicity about the municipal workers has contributed to the residents' withholding of payments for municipal services. In this case, 
Jamela (2016) reiterates that there should be adequate communication as it enhances understanding between two people, clarifies emotional signal, builds a good relationship, and manages diversity.

The recommendations for this study are made to municipal workers and the residents.

\section{Recommendations to the Municipal Workers}

- The municipal management should ensure that adequate service provision is delivered to all the residents equitably.

- There should be a competent service enforcement team who will consistently identify owing or defaulting residents. Disconnection of water should be employed.

- Adequate communication should be established between the municipality and the residents.

- Service centres should always remind the defaulting residents on the need to pay for their accounts.

- IDP meetings should always be arranged to educate the residents on the income and expenditure of the municipality and to make decisions on the way forward.

- Appeal system must be perfect so that misunderstandings between the municipality and the residents be resolved.

- Municipal workers should always collaborate with the political heads to ensure that residents will pay their bills.

- Electronic media such as the e-mail, WhatsApp, Short Message Service (SMS) should be employed to serve as reminders to the owing and defaulting residents.

- Municipalities should employ different kinds of payment options such as Electronic Funds Transfer (EFT), Mobile Payment, and Bank Payment to ease the traditional office/shop queuing method of payment.

- All indigent residents, such as the unemployed and minor-headed households should be identified so that they will be removed from the payment list.

- The municipal workers should always account for all the income and expenditure in every financial year.

- The municipal employees should employ adequate payment education to enlighten the residents about entitlement issues and the need to pay for the services consumed.

- Increased efficiency should be maintained by conducting researches to know where municipalities fall short of performance, immediate corrective actions should be taken adequately.

- Qualified and competent personnel should be engaged to manage the affairs of the municipality and to reduce mistakes in billing.

- Alternatively, debts could be sold to third parties for collection to enable municipalities to recover an outstanding amount of debt.

\section{Recommendations to the Residents}

- All residents should always endeavour to pay their bills as adequate payment of bills will enhance effective service provision.

- Residents should always report to municipalities in the case of poor service provision rather than withholding payment as a payback strategy.

- Inconsistencies in billing should always be reported to the municipal management for reconciliation.

- No resident should connect water illegally after disconnection, in this case, all residents should be on the watch to identify and report any resident that tends to connect water illegally after disconnection by the municipality.

- All indigent or minor-headed households should report to the municipalities to facilitate the indigent policy.

- Residents should always ask for the municipal accounts rather than embarking on negative publicity on municipal financial mismanagement.

- All residents should know that any land in a municipal area belongs t o the municipality, all bills forwarded to them on the use of land, or services provided should be paid to the municipality. 


\section{Conclusion of the Study}

This paper examined the origin of payment default and non-payment culture for municipal services, causes, and the solutions to enhance the payment culture of residents. It was discovered that the non-payment culture for municipal services originated during the Apartheid struggle as a payback to the leaders due to inequitable resource allocation and poor service delivery to the black municipalities. However, it is noted that residents are presently imbibing the non-payment culture due to the inability of municipalities to apply adequate enforcement capacity to mobilise payment as constitutionally stipulated. The study discovered that the main causes of non-payment for municipal services include corruption of municipal officers, poor service provision, decision-making issues, and mismanagement of public funds. Other reasons include lack of implementation of credit policies, negative media publicity, lack of enforcement capacity, the culture of entitlement, discrepancies in the billing system, inability to pay bills, and political discouragement. The study discovered that there is a lack of communication between municipality employees and councillors which result in a reluctance to collaboratively manage payment default. The study discovered that the residents do not report their indigence status which adds up to the total consumer debts. The study believes that both the municipal employees, residents and the political class (councillors) are responsible for the persevered non-payment culture for municipal services. Therefore, municipal employees should reconcile these differences and endeavour to mobilise all payments from residents/service consumers to perform exceedingly in their service provision bid. This study concludes by recommending that municipalities should employ adequate enforcement capacity to collect debts and embark on effective communication to convince and educate the residents to pay for services consumed. This gesture will assist to establish a responsible payment culture for municipal services.

\section{References}

Al-Maghrebi, M. S., Ahmed, R., \& Palil, M. R. (2016). Budget transparency and tax awareness towards tax compliance: a conceptual framework. South East Asia Journal of Contemporary Business, Economics and Law, 10(1), 95-101.

Bastida, F., Beyaert, A., \& Benito, B. (2013). Electoral cycles and local government debt management: Local government Studies. Journal for Economics, 39(110), 107-132.

Bellamy, R. (2008). Citizenship: A very short Introduction. Oxford: Oxford University Press.

Binswanger-Mkhize, H. P., Bouruignon, C., \& van den Brink, R. (2009). From failure to success in South African land reform. Washington DC: World Bank Series.

Binza, S. M. (2000). The evolution of South African local governments: the politics of memory. Retrieved 20th September 2019

from http://digitalknowledge.cput.ac.za/xmlui/bitstream/handle/11189/1266/contemp_v30_n2a5.pdf?sequence=1

Christianson, D. (1994). Local Government the Loser. Retrieved 10th May 2019, from city.blogspot.co.za/2010/06/decision-making-process-in-management.html

Creswell, J. W. (2014). Research design: qualitative, quantitative, and mixed methods approach (4th ed.). CA: Sage Publications.

DBSA Report. (1998).

DeCuir-Gunby, J. T., \& Schutz, P. A. (2017). Developing a mixed methods proposal: a practical guide for beginning researchers. London: Sages Publishers.

Enwereji, P. C. (2018). A payment culture framework for municipal services in the North West province. Mafikeng: North West University, PhD Thesis.

Enwereji, P. C., \& Kadama, F. R. (2018). Payment of residential property rates in a selected district municipality in South Africa. International Journal of Economics and Financial Issues, 8(2), 277-286.

Enwereji, P. C., \& Portgeiter, M. (2018). Establishing a responsible payment culture for municipal services in the North West province: a conceptual framework. International Journal of Economics and Financial Issues, 8(3), 227-234.

Enwereji, P. C., \& Uwizeyimana, D. (2019). Enhancing payment for municipal services through communication dynamics and emerging innovation options. Journal of Gender, Information and Development in Africa (JGIDA), 195-226. 
Fjielstad, O., Schulz-Hherzenberg, C., \& Sjurse, I. (2012). Peoples view of taxation in Africa: a review of research on determinants of tax compliance. MPRA Working Paper, 2(2), 8-12.

Horth, D., \& Bunchner, D. (2014). Innovation leadership: How to use innovation to lead effectively, work collaboratively and drive results. Centre for Ccreative Lleadership, Continuum Journals, 31(1), 1-5.

Ivankova, N. V. (2015). Mixed methods application in action research: from methods to community action. London: Sages Publications.

Joel, L. (2020). Payment for municipal services: People would rather pay for DSTV than municipal services. A report of South African Local Government Association on the payment default. Retrieved $20^{\text {th }}$ February 2020, from http://www.702.co.za/articles/366347/people-would-rather-pay-for-dstv-than-municipal-services

Johnston, A. (2014). South Africa: inventing the nation. London: Bloombury.

Kanyane, M. H. (2014). Financial Viability of Rural Municipalities in South Africa: Democracy, Governance and Service Delivery. Journal of Public Economics, 36(1), 305-321.

Kelly, R. (2013). Making Property Tax Work. International center for public policy, Georgia State University, United States. Working paper, 11(1), 1-31.

Khale, S. (2015). Assessment of the quality of municipal services in the city of Tshwane, South Africa. Journal of Corporate Governance and Control, 13(1), 678-695.

Kroukamp, H. (1995). The Culture of Non-payment of Services as a Constraint in Financial Policy Management for Local Authorities in South Africa. SAIPA.

Lund, C. (2011). Land Right and Citizenship in Africa. Uppsala: Nordiska Afrika Institutet Journals, 46(1), 9-16.

Manyaka, R. K. (2014). Collection of municipal own revenue in South Africa: challenge and prospects. Journal of Public Administration, 49(1), 127-139.

Maphologela, S., \& Ngwane, T. (2015). Debate: should township residents pay for municipal services?. Retrieved 27th April 2017, from http://city-press.news24.com/Voices/Debate-Should-township-residents-pay-for-municipal-services-20151015

Marivate, S. P. (2014). The impact of entrepreneurial skills on the viability and long-term survival of small businesses: a case of the city of Tshwane, South Africa. European Journal of Business, Economics and Accountancy, 2(2), 53-72.

Mascagni, G., Nell, C., \& Monkam, N. (2017). One size does not fit all: a field experiment on the drivers of tax compliance and delivery methods in Rwanda. ICTD working paper.

Monkam, N., \& Moore, M. (2015). How property tax would benefit Africa. Feature Articles, 3(1), 11-16.

Moses, I. J. (2002). The Macro-Economic Implications of Infrastructure Investment and Non-payment of Municipal Services: The Good, the Bad and the Real. PhD Thesis, University of the Free State.

Oladipupo, A., \& Obazee, U. (2016). Tax Knowledge, Penalties and Tax Compliance in Small and Medium Scale Enterprises in Nigeria. iBusiness, 8(3), 1-9.

Powell, D., May, A., Ntliziywana, P., \& de Visser, J. (2010). The Withholding of Rates and Taxes in Five Local Municipalities. Local Government Bulletin-Report of the Community Law Centre for SALGA, 12(4), 5-12.

Republic of South Africa. (1996). Constitution of the Republic of South Africa. Pretoria: Government Printers.

Republic of South Africa. (1997). Water Service Act. Pretoria: Government Printers.

Republic of South Africa. (1998). Municipal Structures Act. Pretoria: Government Printers.

Republic of South Africa. (1999). Public Finance Management Act. Pretoria: Government Printers.

Republic of South Africa. (2000). Municipal Systems Act. Pretoria: Government Printers.

Republic of South Africa. (2003). Municipal Financial Management Act. Pretoria: Government Printers.

Republic of South Africa. (2004). Municipal Property Rates Act. Pretoria: Government Printers.

Republic of South Africa. (2005). National Credit Act. Pretoria: Government Printers.

Republic of South Africa. (2007). Municipal Fiscal Powers and Functions Act. Pretoria: Government Printer

Republic of South Africa. (2008). Consumer Protection Act. Pretoria: Government Printers. 
Republic of South Africa. (2015). South African Advertising Research Foundation. Pretoria: Government Printers.

Republic of South Africa. (2015). Statistics South Africa. Pretoria: Government Printers.

Republic of South Africa. (2017). Minister of Cooperative Governance and Traditional Affairs. Pretoria: Government Printers.

Republic of South Africa. (2017). The National Treasury: Budget Review. Pretoria: Government Printers.

Republic of South Africa. (2018). Financial \& Fiscal Commission. Pretoria: Government Printers.

Republic of South Africa. (2018). The National Treasury: Budget Review. Pretoria: Government Printers.

Rosen, H. S., \& Gayer, T. (2013). Public finance (9th ed.). New York: McGraw-Hill Series.

Sikor, T., \& Lund, C. (2010). Politics of Possession, Property, Authority and Assess to Natural Resources. London: Blackwell.

Sithole, S., \& Mathonsi, N. (2015). Local governance service delivery isues during Apartheid and post-Apartheid South Africa. 6 Africa's Public Service Delivery \& Performance Review, 1(1), 1-26.

Timm, J., \& Jadwat, O. (1998). Masakhane Case Studies. Development South Africa, Randburg. Retrieved $24^{\text {th }}$ May 2019, from https://www.nadeosa.org.za/documents/CaseStudies1-7.pdf

Toulmin, C. 2008. Securing Land and Property Rights in Sub-Saharan Africa: The Role of Local Institutions. International Institute for Environmental and Development Journal, 26(1), 10-19.

Worku, Z. (2016). The impact of poor quality municipal services on small enterprises. Investment Management \& Financial Innovations, 14(4), 274-279.

Zimmermann, K. A. (2015). What is culture? - definition of culture. Retrieved 3rd May 2019, from http://www.livescience.com/21478-what-is-culture-definition-of-culture.html 